\title{
Development and Characterization of Rice Husk and Recycled Polypropylene Composite Filaments for 3D Printing
}

\author{
Maria A. Morales ${ }^{1}$, Cindy L. Atencio Martinez ${ }^{1}$, Alejandro Maranon ${ }^{2}$, Camilo Hernandez ${ }^{3}{ }^{\mathbb{C}}$, \\ Veronique Michaud ${ }^{4}$ and Alicia Porras ${ }^{1, *}$ (D) \\ 1 Grupo de Diseño de Productos y Procesos (GDPP), Department of Chemical and Food Engineering, \\ Universidad de los Andes, CR 1 18a 12, Bogotá 111711, Colombia; ma.morales12@uniandes.edu.co (M.A.M.); \\ cl.atencio@uniandes.edu.co (C.L.A.M.) \\ 2 Structural Integrity Research Group, Department of Mechanical Engineering, Universidad de los Andes, \\ CR 1 18a 12, Bogotá 111711, Colombia; emaranon@uniandes.edu.co \\ 3 Sustainable Design in Mechanical Engineering Research Group (DSIM), Department of Mechanical \\ Engineering, Escuela Colombiana de Ingenieria Julio Graravito, Autopista Norte AK 45205 59, \\ Bogotá 111166, Colombia; camilo.hernandez@escuelaing.edu.co \\ 4 Laboratory for Processing for Advanced Composited (LPAC), Institute of Materials, Ecole Polytechnique \\ Fédérale de Lausanne (EPFL), EPFL-STI-IMX-LPAC, Station 12, CH-1015 Lausanne, Switzerland; \\ veronique.michaud@epfl.ch \\ * Correspondence: n-porras@uniandes.edu.co; Tel.: +57-1-3394999 (ext. 1775)
}

check for

updates

Citation: Morales, M.A.; Atencio Martinez, C.L.; Maranon, A.; Hernandez, C.; Michaud, V.; Porras, A. Development and Characterization of Rice Husk and Recycled Polypropylene Composite Filaments for 3D Printing. Polymers 2021, 13, 1067. https://doi.org/10.3390/ polym 13071067

Academic Editor: Chin-San Wu

Received: 1 March 2021

Accepted: 25 March 2021

Published: 28 March 2021

Publisher's Note: MDPI stays neutral with regard to jurisdictional claims in published maps and institutional affiliations.

Copyright: (c) 2021 by the authors. Licensee MDPI, Basel, Switzerland. This article is an open access article distributed under the terms and conditions of the Creative Commons Attribution (CC BY) license (https:// creativecommons.org/licenses/by/ $4.0 /)$.

\begin{abstract}
Nowadays the use of natural fiber composites has gained significant interest due to their low density, high availability, and low cost. The present study explores the development of sustainable 3D printing filaments based on rice husk $(\mathrm{RH})$, an agricultural residue, and recycled polypropylene (rPP) and the influence of fiber weight ratio on physical, thermal, mechanical, and morphological properties of $3 \mathrm{D}$ printing parts. Thermogravimetric analysis revealed that the composite's degradation process started earlier than for the neat rPP due to the lignocellulosic fiber components. Mechanical tests showed that tensile strength increased when using a raster angle of $0^{\circ}$ than specimens printed at $90^{\circ}$, due to the weaker inter-layer bonding compared to in-layer. Furthermore, inter layer bonding tensile strength was similar for all tested materials. Scanning electron microscope (SEM) images revealed the limited interaction between the untreated fiber and matrix, which led to reduced tensile properties. However, during the printing process, composites presented lower warping than printed neat rPP. Thus, 3D printable ecofriendly natural fiber composite filaments with low density and low cost can be developed and used for 3D printing applications, contributing to reduce the impact of plastic and agricultural waste.
\end{abstract}

Keywords: composites; rice husk; recycled polypropylene; 3D printing; fused filament fabrication

\section{Introduction}

The fourth industrial revolution allows alternative industrial models where materials are repurposed for further uses taking advantage of digital technologies [1]. Some of these materials are plastic waste sent to be recycled [2] and agricultural residues [3]. One of those technologies is 3D printing [4].

In particular, plastic waste has increased dramatically since polymers' industrial production started in the 20th century: $79 \%$ of plastics produced to date has been accumulated in dumps or landfilled [5], remaining in the environment for extended periods [6-9], even contaminating the food chain [10-13]. Therefore, developing practical and sustainable alternatives to reduce such waste has attracted significant interest by producing parts from recycled resources [14-16]. Moreover, agricultural residues are becoming an environmental problem as only a minimal fraction of the 155 billion tons/year of organic matter production from the photosynthetic process can be consumed directly by humans or animals [17]. Residues become waste as they do not have commercial use [17-19], affecting human 
health and damaging the environment [20-22]. Therefore, the safe disposition or recycling of agricultural waste has been considered paramount in the green economy [23-26].

On the other hand, 3D printing is a rapidly evolving digital technology [27,28], enabling the automatic fabrication of complex shapes with minimum material waste $[29,30]$ for many applications such as automotive, aerospace, construction, and medicine [31-34]. Among 3D printing technologies, the Fused Filament Fabrication (FFF) is the least expensive, producing parts using multiple different materials $[30,35,36]$. In the FFF process, a polymeric filament is continuously fed into a heated nozzle that melts the polymer, layering it in thin slabs onto a print bed, forming a 3D part [37-40]. Commonly, amorphous or low crystallinity thermoplastics, such as ABS, nylon, or PLA, are used as feedstock materials for FFF [41-43], as they exhibit a low degree of warping, which contributes to dimensional accuracy [44].

Recently, agricultural residues have been used as a loading material for 3D printing [45-53] as they reduce warping [54-57], enhance printing directionality [58-60], and display high specific mechanical properties [61-63]. However, in FFF there are some standing issues such as residues' agglomeration, viscosity variations, high porosity, low thermal stability [64], and non-uniform physical and mechanical properties [61]. One particular example of these residues is rice husk (RH), which most accumulates in Colombia, reaching about 63 tons/day [20]. Studies using RH as load material have found that the mechanical properties of samples are affected by the printing direction [59], that adding methylene diphenyl diisocyanate improves the mechanical performance reducing the presence of voids [65], and that acrylic acid grafting on PLA enhances tensile and physical properties of PLA/RH printed specimens [66].

Moreover, there is a growing interest in using amorphous and low-crystalline recycled plastics, like PLA [67] and PET [68], as feedstock materials for printing biocomposites. However, the use of semi-crystalline recycled plastics, such as polypropylene, has been limited [69-71] due to the printed parts' tendency to warp and shrink [72,73]. In Colombia, polypropylene is produced at about 500,000 tons/year [74], and it is one of the major contributors to marine and urban pollution [75].

Although natural fibers-filled polymers are gaining importance in the 3D printing market and remarkably growing interest from the scientific community, several new agro-waste natural fiber sources and polymer combinations remain to explore their potential structural and economic performance in FFF applications. In particular, rice husk reinforced recycled polypropylene composite is a novel feedstock for 3D printing applications. Therefore, in this work, rice husk and recycled polypropylene are employed to develop and characterize a sustainable composite filament for use in the Fused Filament Fabrication process. The manufacturing process of the composite filament is fist described. Physical, mechanical, thermal, and morphological properties of 3D printed specimens using this novel composite filament are characterized. Density, water absorption, thermogravimetric analysis, tensile test, and electronic microscopy were used to explore printed structures properties with different rice husk content (fiber weight ratio). Additionally, different printing raster angles were employed to explore the variation of mechanical properties with printing direction. All properties were compared against the benchmark neat recycled PP.

\section{Materials and Methods}

\subsection{Materials}

Promaplast S.A.S. supplied recycled polypropylene (rPP) pellets from post industrial waste.

Rice husk was obtained from Ambala grinder from the Tolima Department, in Colombia.

\subsection{Extrusion of Composite Filaments}

Pulverisette 19 mill was used to grind the RH to reduce particles' size, to reach a particle size between 250 and $425 \mu \mathrm{m}$. Before mixing, pulverized RH and rPP pellets were 
dried at $105{ }^{\circ} \mathrm{C}$ for three hours. Compounds were prepared by weighing RH fiber and rPP to obtain 0,5 and $10 \mathrm{wt} . \%$ fiber content, and hand mixing before feeding to the extruder.

A Brabender DSE 20 twin extruder with six temperature-controlled zones was used for extrusion. The feed port was fixed at $180^{\circ} \mathrm{C}$ and the adjacent zone to $185^{\circ} \mathrm{C}$. The following two zones were fixed at $190{ }^{\circ} \mathrm{C}$. The last zone was set at $195{ }^{\circ} \mathrm{C}$ and the die at $195^{\circ} \mathrm{C}$. Screw speed was maintained at $9 \mathrm{rpm}$. The extruded filament was collected on water at a temperature of $25^{\circ} \mathrm{C}$. The resulting material was granulated in a pelletizer and re-extruded to improve homogenization of the mixture. Extruder parameters for the second extrusion were set at the same values as the first. A $2 \mathrm{~mm}$ diameter nozzle was used to generate filaments with a target diameter of $1.75 \pm 0.05 \mathrm{~mm}$ (Figure 1).

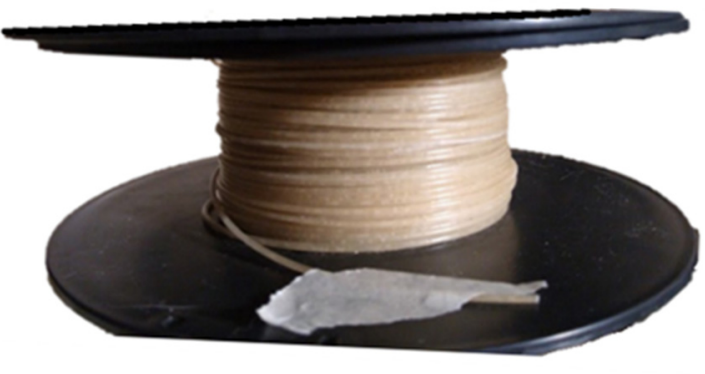

(a)

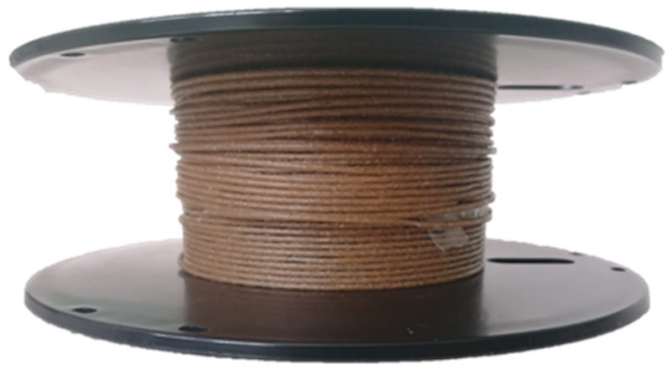

(b)

Figure 1. rPP/RH 3D printing filaments with (a) 5 wt.\% and (b) $10 \mathrm{wt} . \%$ of RH.

\subsection{Density}

Density of $\mathrm{rPP}$ and $\mathrm{rPP} / \mathrm{RH}$ composites was measured following the ASTM D792, test method B, using ethanol $\left(\rho=0.789 \mathrm{~g} / \mathrm{cm}^{3}\right)$ at $19.9^{\circ} \mathrm{C}$ as immersion liquid. An electronic balance was used to weigh the specimens. Three specimens were tested per material.

\subsection{Water Absorption and Diameter Swelling Test}

Three specimens per material (length $=50 \pm 0.1 \mathrm{~mm}$ ) were prepared according to the ASTM D570 standard to test the percentage increase in weight. Preconditioning of the specimens was carried out, specimens were dried at $50{ }^{\circ} \mathrm{C}$ for $24 \mathrm{~h}$, cooled in a desiccator, and immediately weighted $\left(\mathrm{W}_{0}\right)$. Later specimens were immersed in distilled water for $2 \mathrm{~h}$ at room temperature, all surface water wiped off with a dry cloth, and weighed $\left(\mathrm{W}_{\mathrm{i}}\right)$. The weight percentage increase during the immersion, was calculated using Equation (1).

$$
\text { Increase in weight (weight \%) }=\left(\mathrm{W}_{\mathrm{i}}-\mathrm{W}_{0}\right) / \mathrm{W}_{0} \times 100
$$

The swelling diameter of the composite was determined by measuring the diameter of each specimen before $\left(D_{0}\right)$ and after $\left(D_{i}\right)$ water immersion test, according to Equation (2).

$$
\text { Diameter swelling }(\%)=\left(D_{i}-D_{0}\right) / D_{0} \times 100
$$

\subsection{Thermal Analysis}

A thermogravimetric analyzer (SDT Q600) was used to characterize the composites' thermal stability and the neat polymer, subjected to the same extrusion process as the composites. Measurements were performed in nitrogen atmosphere with sample weight of $2 \mathrm{mg}$ according to the ASTM E1131 standard. Samples were heated from ambient temperature to $700{ }^{\circ} \mathrm{C}$ at a rate of $10^{\circ} \mathrm{C} / \mathrm{min}$. Further thermal analysis was carried out according to the ASTM D3418 standard using a DSC Q2000. First, sample temperature was increased from the ambient temperature to $220^{\circ} \mathrm{C}$, at a heating rate of $10^{\circ} \mathrm{C} / \mathrm{min}$ and held in an isothermal state for $5 \mathrm{~min}$, to eliminate thermal history, residual moisture, and voids. Then, the sample was cooled down to room temperature at $10{ }^{\circ} \mathrm{C} / \mathrm{min}$, and 
reheated to $220^{\circ} \mathrm{C}$ at $10^{\circ} \mathrm{C} / \mathrm{min}$. The samples' degree of crystallinity was calculated by Equation (3) $[69,76,77]$, considering the polymer fraction in the material [78-80].

$$
\% \text { crystallinity }=\left(\Delta \mathrm{H}_{\mathrm{f}}{ }^{\text {obs }} / \Delta \mathrm{H}_{\mathrm{f}}{ }^{0}\right) \times 100 /\left(100-\mathrm{w}^{\mathrm{f}}\right)
$$

where $\Delta \mathrm{H}_{\mathrm{f}}$ obs is the observed enthalpy of fusion, $\Delta \mathrm{H}_{\mathrm{f}}{ }^{0}$ the heat of fusion of the completely crystalline materials at the equilibrium melting temperature $T_{m}(207 \mathrm{~J} / \mathrm{g}[81-83])$ and $\mathrm{w}^{\mathrm{f}}$ is the fiber weight ratio in composites.

\subsection{Specimen Manufacturing}

According to the ASTM D3039/3039-08 standard $(200 \mathrm{~mm} \times 25 \mathrm{~mm} \times 2.5 \mathrm{~mm})$ on a 3D FF STD Doppia machine, the filament was printed into tensile specimens. STL files were imported into Simplify3D for editing. The filament was printed on a Magigoo 3D Printing Adhesive for PPGF using a brim platform to avoid warping effects for all samples. Bed temperature for the first layer was set to $90^{\circ} \mathrm{C}$, and $70{ }^{\circ} \mathrm{C}$ for the rest of the layers. Nozzle temperature was set to $240{ }^{\circ} \mathrm{C}$. The layer height was set to $0.25 \mathrm{~mm}$, with a nozzle diameter of $0.8 \mathrm{~mm}, 100 \%$ infill, and a printing speed of $60 \mathrm{~mm} / \mathrm{s}$. Two types of specimens were printed at different raster angles, $0^{\circ}$ and $90^{\circ}$, to determine the tensile properties as a function of the raster angle. 3D printed specimens are shown in Figure 2.

(a)

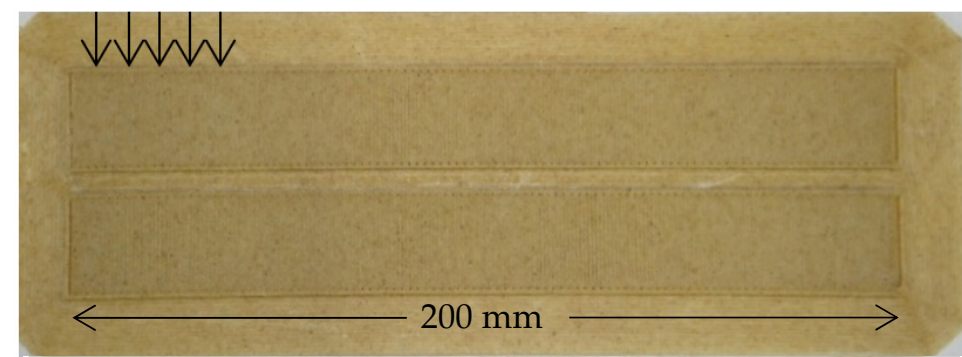

(b)

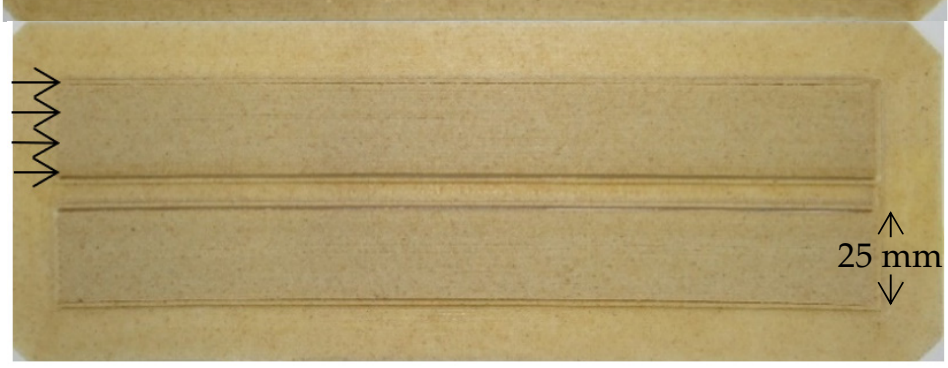

Figure 2. 3D printing tensile specimens at (a) $90^{\circ}$ and (b) $0^{\circ}$ with brim platform.

\subsection{Mechanical Measurements}

Uniaxial tensile tests were conducted on an Instron 3367 universal testing machine, equipped with a $30 \mathrm{kN}$ load cell according to the ASTM D3039/3039 standard. Five tensile specimens were tested per composition and print conditions until failure. Tensile tests were performed at a gauge length of $50 \mathrm{~mm}$ and a crosshead speed of $10 \mathrm{~mm} / \mathrm{min}$, and $1.2 \mathrm{~mm} / \mathrm{min}$ for specimens printed at $90^{\circ}$ and $0^{\circ}$ respectively. Strain was measured for all specimens using an extensometer fixed to the samples.

\subsection{Statistical Analysis}

Physical and mechanical properties of materials are influenced by different parameters, including fiber weight ratio. Analysis of variance is the central technique in the experimental data analysis. It consists of dividing the total variation observed in each of the sources that contribute to it. ANOVA assesses the importance of one or more factors by comparing the response variable means at the different factor levels [84].

In this study, a one-way analysis of variance was carried out, considering the fiber content as the factor, with three levels $(0 \mathrm{wt} . \%, 5 \mathrm{wt} . \%$ and $10 \mathrm{wt} . \%)$. Three specimens were evaluated for density, and five specimens were tensile tested for each configuration. Density, 
water absorption, tensile strength and Young's modulus were used as analysis criteria (response variable). To this purpose, a $p$-value of $p<0.05$ was considered statistically significant. Minitab 18 Statistical Software was used to analyze data. An analysis of variance was carried out for each $3 \mathrm{D}$ printing raster angle.

\subsection{Scanning Electron Microscopy Measurements}

Fractures of failed tensile composites specimens were observed using a JEOL SEM JSM-6490LV. Specimens were prepared by gold-sputtering for $1 \mathrm{~min}$ at $20 \mathrm{~mA}$ to obtain good conductivity.

\section{Results and Discussion}

\subsection{Physical Properties}

Table 1 reports density values for the neat rPP and the composites. As expected, the density decreased with increasing fiber content and showed small variations. This decrease is due to the lower density of the filler fiber (between 0.88 and $0.12 \mathrm{~g} / \mathrm{cm}^{3}$ ) as compared to $\operatorname{rPP}\left(0.89 \mathrm{~g} / \mathrm{cm}^{3}\right)[59,85]$. The rPP with $10 \mathrm{wt} . \%$ of RH showed a density decrease of $2.0 \%$ as compared to rPP. This result is consistent with other results reported for wood apple shell reinforced epoxy composites [86], foams reinforced with cassava starch [87], and foams reinforce with cassava/sugar palm [88]. This density reduction is greater (up to $3.8 \%$ ) if the results are compared against neat $\mathrm{PP}$ (which has a slightly higher density than $\mathrm{rPP}$, at $0.91 \pm 0.01 \mathrm{~g} / \mathrm{cm}^{3}$ ) [89]. According to the statistical analysis with a significance of $5 \%$, the fiber weight ratio has a significant impact on the density of composite materials. Further analysis was made with a Tukey test, obtaining a significant difference between rPP and $\mathrm{rPP} / \mathrm{RH}(10 \mathrm{wt} . \%)$ composite densities.

Table 1. Density of neat $\mathrm{rPP}$ and $\mathrm{rPP} / \mathrm{RH}$ composites.

\begin{tabular}{cc}
\hline Sample & Density $\left(\mathrm{g} / \mathrm{cm}^{3}\right)$ \\
\hline $\mathrm{rPP}$ & $0.893 \pm 0.001$ \\
$\mathrm{rPP} / \mathrm{RH}(5 \%)$ & $0.883 \pm 0.004$ \\
$\mathrm{rPP} / \mathrm{RH}(10 \%)$ & $0.876 \pm 0.004$ \\
\hline
\end{tabular}

Low-density composites are widely used in different industries. For example, the lower overall weight of composites based on natural fibers is advantageous in the automotive industry since light parts increase fuel efficiency and increase the sustainability of the manufacturing process [90-92].

Water absorption and diameter swelling of the filaments were measured to compare the hydrophobic behavior of rPP and rPP/RH composites. As shown in Figure 3., rPP/RH composites have a higher water absorption and a higher swelling diameter due to natural fibers' hydrophilic behaviors $[29,66,93-95]$. These parameters increase with fiber weight ratio. Razavi et al. investigated the water absorption behavior of chopper rice husk-filled polypropylene composites manufactured through injection molding, his study showed that a higher weight fiber increases water absorption, reaching about $300 \%$ with $10 \mathrm{wt} . \%$ of $\mathrm{RH}$, compared to neat PP [96]. Obtained results for composites were similar to reported values obtained for PLA and PHA and natural fibers composites [45,97]. The importance of drying the fibers well before the composites processing, lies in the fact that natural fibers' moisture and swelling behavior induce debonding between fibers and matrix [98-104]. Moreover, a reduction in mechanical properties and degradation temperature has been observed due to high level moisture absorption by natural fibers $[98,105,106]$. Improvement in water absorption and swelling diameter could be reached by surface treatment $[98,105,107]$. 


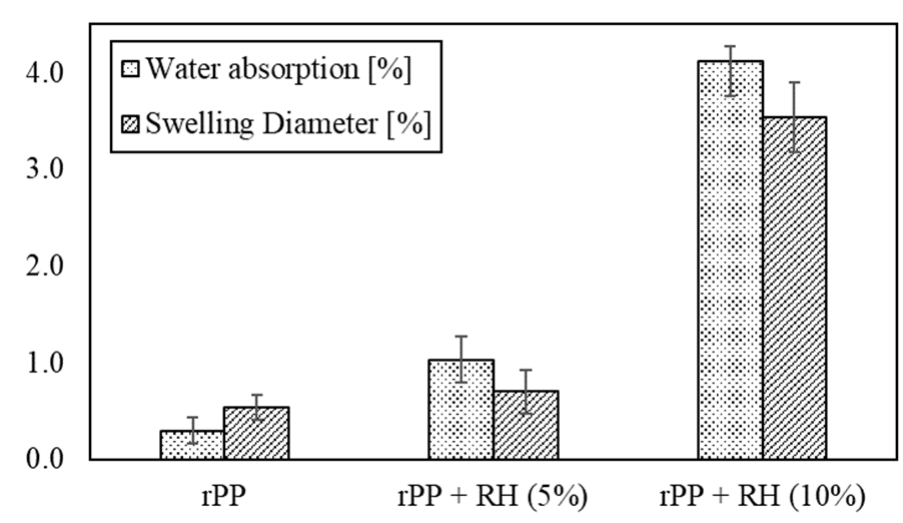

Figure 3. Water absorption and swelling diameter of $\mathrm{rPP}$ and $\mathrm{rPP} / \mathrm{RH}$ composites.

\subsection{Thermal Analysis}

Thermal stability of RH fiber, neat rPP, rPP/RH (5 wt.\%) and rPP/RH (10 wt.\%) was studied by thermo-gravimetric analysis. Figure 4 shows the percentage weight change and the derivative of weight as a function of each material's temperature. For the RH fibers, three stationary regimes are observed. A first phase ranging from 50 to $100{ }^{\circ} \mathrm{C}$ is linked to the moisture content of the fiber, representing $10 \%$ of the weight; the second phase, with a significant decay at $280{ }^{\circ} \mathrm{C}$ is related to the degradation of hemicelluloses and partial decomposition of lignin, and the third point at $340{ }^{\circ} \mathrm{C}$ is associated with $\alpha$-cellulose and remaining lignin degradation [108]. The observed thermal behavior of RH was similar to that of other lignocellulosic fibers $[19,29,109]$. For the rPP curves, a small weight change is observed between 165 and $175^{\circ} \mathrm{C}$, attributed to impurities' presence due to the recycled nature of the polymer. Moreover, between 400 to $490{ }^{\circ} \mathrm{C}$ a main step is associated with the main degradation of the polypropylene. $\mathrm{rPP} / \mathrm{RH}(5$ and $10 \mathrm{wt} . \%$ ) curves present combined loss behavior. The first step ranging from 50 to $120^{\circ} \mathrm{C}$ is attributed to the evaporation of moisture. The next two steps represent the fiber components degradation, and the last represents the matrix degradation at $460{ }^{\circ} \mathrm{C}$. Finally, for $\mathrm{RH}$ and $\mathrm{rPP} / \mathrm{RH}$ ( 5 and $10 \mathrm{wt} . \%$ ) composites, the residual mass percentage at $600{ }^{\circ} \mathrm{C}$ was around $34.45 \%, 3.52 \%$, and $3.88 \%$, respectively.

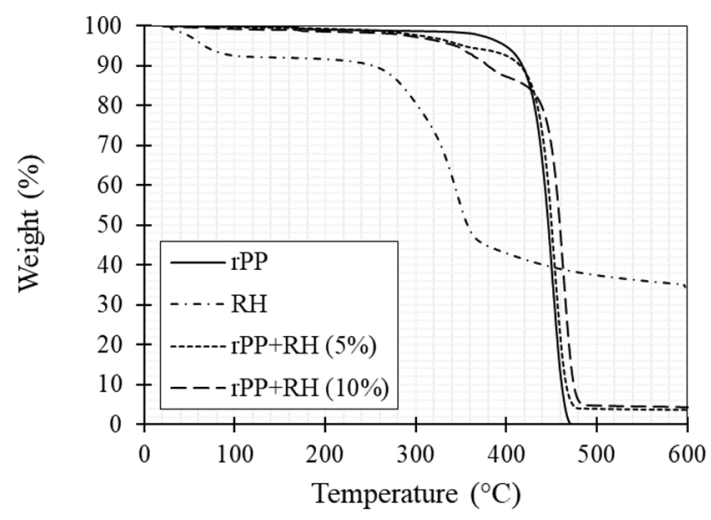

(a)

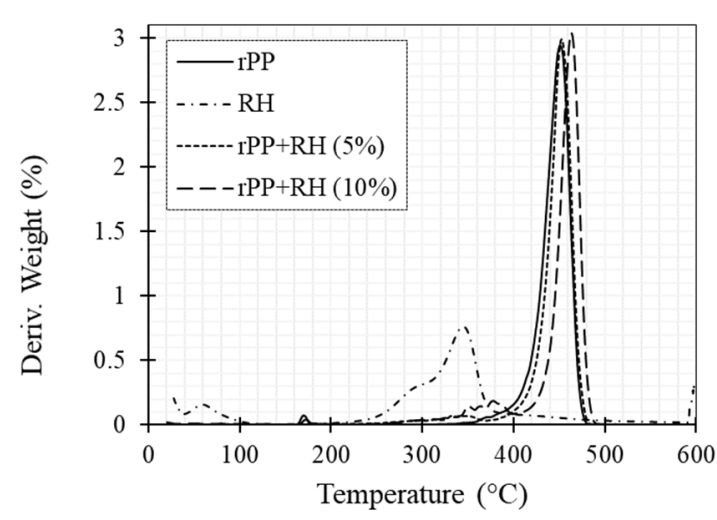

(b)

Figure 4. (a) TGA and (b) DTGA curves of RH fiber, rPP and rPP/RH composite filaments obtained using TGA.

In summary, these results show that fiber thermal degradation may occur during the printing process with an extruder temperature above $280^{\circ} \mathrm{C}$. However, with adequate printing temperature, $\mathrm{rPP} / \mathrm{RH}$ composites stability is a priori suitable for $3 \mathrm{D}$ printing applications.

Thermal phase transitions of the samples were measured with DSC. Figure 5 shows the crystallization and melting transition curves of $\mathrm{rPP}$ and $\mathrm{rPP} / \mathrm{RH}$ (5 and $10 \mathrm{wt} . \%)$. In 
Figure 5a, endotherms show that the rPP has a well-defined melt transition centered at $167.27^{\circ} \mathrm{C}$. The phase transformation occurs between 130 and $175^{\circ} \mathrm{C}$. The melting behavior of the composites is very similar to that of rPP. The melting endotherm display a small peak at around $185^{\circ} \mathrm{C}$, which can be attributed to impurities due to its recycled nature.

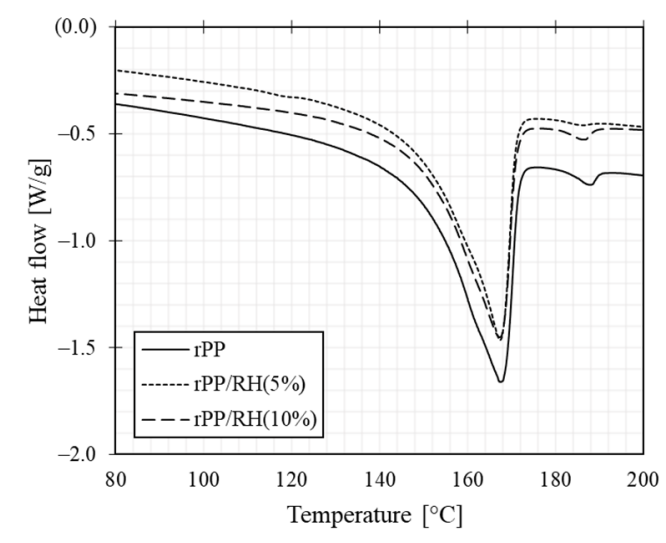

(a)

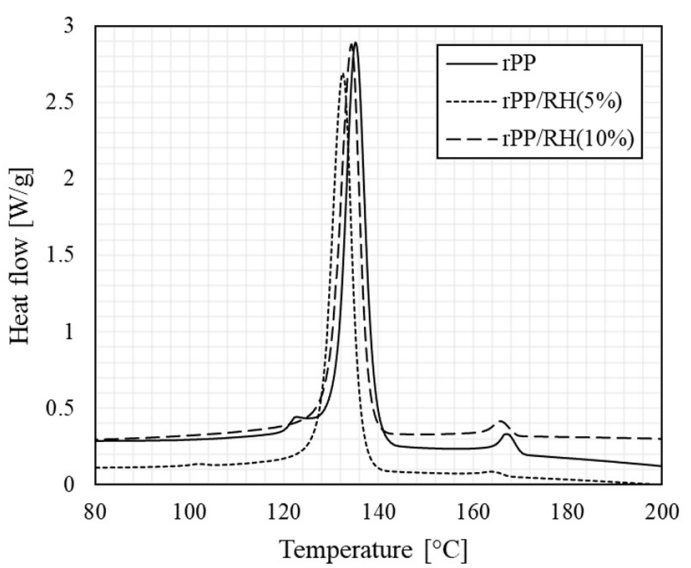

(b)

Figure 5. (a) DSC melting and (b) crystallization thermograms of $\mathrm{rPP}$ and $\mathrm{rPP} / \mathrm{RH}$ composites.

Exotherms shown in Figure $5 \mathrm{~b}$ indicates that the crystallization temperature of $\mathrm{rPP}$ is $135.07^{\circ} \mathrm{C}$. Phase transformation occurs between 125 and $145^{\circ} \mathrm{C}$. The composite materials corresponding crystallization temperatures decrease to 132 and $134^{\circ} \mathrm{C}$ for $\mathrm{rPP} / \mathrm{RH}(5 \%)$ and $\mathrm{rPP} / \mathrm{RH}(10 \%)$, respectively. These temperatures suggest a lower crystallization rate [110], than the neat $\mathrm{rPP}\left(135^{\circ} \mathrm{C}\right)$. This feature is crucial as it may imply a decrease of the warping effect during the composites' printing process compared to the neat rPP.

$\mathrm{RH}^{\prime}$ 's presence in the rPP matrix is known to interact with the crystallization process of the rPP and decrease its crystallization temperature. As shown in Table 2, this may be caused by RH's inhibition effect on the rPP crystal formation [111,112].

Table 2. Temperatures and enthalpies of fusion and crystallization of $\mathrm{rPP}$ and $\mathrm{rPP} / \mathrm{RH}$ composites.

\begin{tabular}{|c|c|c|c|c|c|}
\hline \multirow[b]{2}{*}{ Sample } & \multicolumn{2}{|c|}{ Crystallization } & \multicolumn{2}{|c|}{ Melting } & \multirow{2}{*}{$\begin{array}{c}\% \text { Crystallinity } \\
\text { Based on } \\
\Delta \mathrm{H}_{\mathrm{PP}}{ }^{0}\end{array}$} \\
\hline & $\begin{array}{c}\mathrm{T}_{\mathrm{c}} \\
\left({ }^{\circ} \mathrm{C}\right)\end{array}$ & $\begin{array}{l}\Delta \mathbf{H}_{\mathrm{c}} \\
(\mathrm{J} / \mathrm{g})\end{array}$ & $\begin{array}{c}\mathrm{T}_{\mathrm{m}} \\
\left({ }^{\circ} \mathrm{C}\right)\end{array}$ & $\begin{array}{c}\Delta H_{m} \\
(J / g)\end{array}$ & \\
\hline $\mathrm{rPP}$ & 135.07 & 84.28 & 167.27 & 94.83 & 45.81 \\
\hline $\mathrm{rPP} / \mathrm{RH}(5$ wt.\%) & 132.39 & 81.01 & 167.39 & 73.98 & 37.62 \\
\hline rPP/RH (10 wt.\%) & 134.26 & 84.63 & 167.24 & 80.54 & 43.23 \\
\hline
\end{tabular}

On the other hand, when increasing the fiber fraction from 5 to $10 \mathrm{wt} . \%$, a slight increase of the crystallinity, from 37.62 to $43.23 \%$, is observed. It can point to the possibility that RH fiber, if in sufficient quantity, acts as nucleating sites, causing the acceleration of the crystallization of the composite $[109,113]$.

\subsection{Mechanical Properties}

During the 3D printing of tensile specimens, as speculated with thermal results, composites exhibited less warping effect than neat rPP. Figure 6 shows the representative stress-strain curves for $3 \mathrm{D}$ printed tensile specimens at $0^{\circ}$ and $90^{\circ}$ of $\mathrm{rPP}$ and $\mathrm{rPP} / \mathrm{RH}$ composites with $5 \%$ and $10 \mathrm{wt} . \% \mathrm{RH}$. These curves show an initial linear elastic region followed by plastic deformation up to failure. Comparing the raster angle evaluated, curves for $\mathrm{rPP} / \mathrm{RH}$ composites at different fiber weight ratios show similar behaviors, which is an advantage in fiber implementation and potential variability. For specific applications of 3D 
printing filaments, the use of lighter components is preferable. In this case, adding $10 \mathrm{wt} . \%$ of fiber does not significatively affect the strain to failure, denoting that $10 \mathrm{wt} . \%$ of fiber can be used to develop of 3D printing filaments and prototypes.

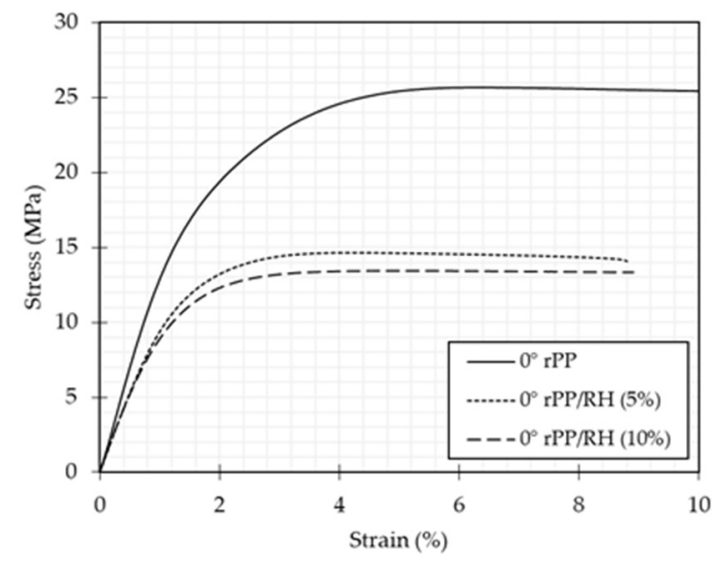

(a)

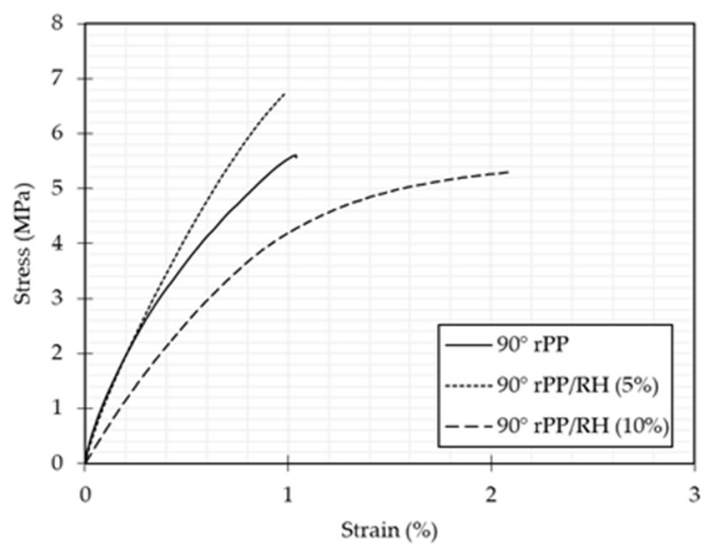

(b)

Figure 6. Stress-strain curve for $\mathrm{rPP}$ and $\mathrm{rPP} / \mathrm{RH}(5$ and $10 \mathrm{wt} . \%)$ composites (a) printed at $0^{\circ}$ and (b) printed at $90^{\circ}$.

However, for $0^{\circ}$ specimens, neat rPP is stiffer and has a significantly higher toughness than the composites, as evaluated from the area under the curves, showing that it is more susceptible to dissipate energy. Instead, for $90^{\circ}$ angle $\mathrm{rPP} / \mathrm{RH}(5 \%)$ are stiffer than neat $\mathrm{rPP}$ and $\mathrm{rPP} / \mathrm{RH}(10 \%)$ and has better ultimate strength. Moreover, for $90^{\circ} \mathrm{rPP} / \mathrm{RH}(10 \%)$ an increase in toughness is observed. Even though, the mechanical properties of $\mathrm{rPP} / \mathrm{RH}$ composites are in general lower than those of the neat $\mathrm{rPP}$, results demonstrate that rice husk can be considered as a potential filler since using a raster angle of $0^{\circ}$, there is no significant difference in mechanical properties between 5 and $10 \mathrm{wt}$ \% of fiber. Besides, using $10 \mathrm{wt}$.\% of rice husk and a raster angle of $90^{\circ}$, the material is more ductile and has a higher energy absorption capacity.

Table 3 summarizes the tensile properties of $\mathrm{rPP}$ and $\mathrm{rPP} / \mathrm{RH}$ composites printed at different raster angles. The printed specimens' orthotropic nature is attributed to the difference between bonding mechanisms at $0^{\circ}$ and $90^{\circ}$ of raster angle, as the inter-layer connection is weaker than in-layer [114]. Guen et al. [59] also observed the orthotropyinduced difference in properties between the lengthwise $\left(0^{\circ}\right)$ and widthwise $\left(90^{\circ}\right)$ printing raster angle. When a tensile test is carried out in specimens printed at $90^{\circ}$, the main mechanism of failure is the detachment of layers. In other words, the adhesion between layers is evaluated in these tests. Whereas with the tensile test of specimens printed at $0^{\circ}$, the intrinsic material properties are evaluated.

Table 3. Mechanical properties of $\mathrm{rPP}$ and $\mathrm{rPP} / \mathrm{RH}$ composites at different raster angles.

\begin{tabular}{ccccc}
\hline Raster Angle & Specimen & $\begin{array}{c}\text { Tensile Strength } \\
\mathbf{( M P a})\end{array}$ & $\begin{array}{c}\text { Tensile Elongation } \\
\mathbf{( \% )}\end{array}$ & $\begin{array}{c}\text { Young Modulus } \\
(\mathrm{GPa})\end{array}$ \\
\hline \multirow{2}{*}{$0^{\circ}$} & $\mathrm{rPP}$ & $26.02 \pm 0.47$ & $6.16 \pm 0.19$ & $1.34 \pm 0.05$ \\
& $\mathrm{rPP} / \mathrm{RH}(5 \mathrm{wt} . \%)$ & $13.62 \pm 2.71$ & $4.10 \pm 0.20$ & $1.06 \pm 0.13$ \\
& $\mathrm{rPP} / \mathrm{RH}(10 \mathrm{wt.} \%)$ & $13.78 \pm 0.59$ & $5.06 \pm 0.16$ & $1.04 \pm 0.04$ \\
\hline \multirow{2}{*}{$90^{\circ}$} & $\mathrm{rPP}$ & $4.33 \pm 1.73$ & $1.01 \pm 0.35$ & $0.74 \pm 0.37$ \\
& $\mathrm{rPP} / \mathrm{RH}(5 \mathrm{wt} \%)$ & $7.92 \pm 0.67$ & $2.04 \pm 0.43$ & $1.01 \pm 0.12$ \\
& $\mathrm{rPP} / \mathrm{RH}(10 \mathrm{wt} . \%)$ & $5.66 \pm 0.82$ & $3.07 \pm 0.45$ & $0.66 \pm 0.13$ \\
\hline
\end{tabular}

Before data analysis, a statistical analysis was performed. For specimens printed at $0^{\circ}$ and $90^{\circ}$, the fiber weight ratio is significant in tensile strength and tensile elongation. More- 
over, by a Tukey comparison, it was demonstrated that tensile strength is not significantly different between both composites.

A potential explanation for the loss in tensile strength of the composites as compared to the neat $\mathrm{rPP}$ in the $0^{\circ}$ direction is the absence of chemical bonding between $\mathrm{rPP}$ and $\mathrm{RH}$ and the low dispersion of RH on the rPP matrix due to the large differences in the surface energies of the rPP and RH filler $[65,108]$. Osman et al. tested natural fiber 3D printed composites based on ABS and rice straw at $0^{\circ}$. They also reported a loss in tensile strength with fiber addition, by $31.61 \%$ from the neat ABS to ABS and $10 \mathrm{wt} . \%$ of rice straw [115]. In general, comparing unfilled and natural fiber composite printed parts, it is often concluded fiber's addition has a negative influence on strength [55,111,116-119]. Even for composites produced by compression molding, a similar effect is reported by Rice et al. for polypropylene composites made with $20 \%$ of rice husk. The tensile strength decreases by almost $20 \%$ compared to neat polypropylene [19]. Nevertheless, compared with the neat $\mathrm{rPP}$, the composite material has the advantages of a reduced cost and easy processability in reducing of the warping during the $3 \mathrm{D}$ printing process. Moreover, it is important to highlight its lower density for light material application, as in concept parts, lightweight custom jigs and fixtures or thermoformed parts, and the sustainable nature due to the use of recycled polymers and natural fibers for its development.

Figure 7 shows tensile test failure mode of a couple of specimens of each configuration. The fracture mode depends on the raster angle used. For the $0^{\circ}$ angle, presented in Figure 7a,b, fracture occurred perpendicular to the layer's deposition direction with an irregular fracture. According to the failure codes proposed by the ASTM D3039 standard, composite specimens with $5 \mathrm{wt}$.\% of RH tended to fail with an angle at the bottom grip (AGB). Meanwhile those with $10 \mathrm{wt} . \%$ of fiber failed angled in the middle of the specimen (AGM). Those specimens show some ductile mode of failure. An amount of deformation is observed in each $3 \mathrm{D}$ printed layer. For the $90^{\circ}$ raster angle specimens, shown in Figure $7 \mathrm{c}, \mathrm{d}$, the failure occurs through the bonded layers, adjacent to the layers' deposition direction, in a more brittle manner and in the gauge region. The brittle fracture mode of specimens printed at $90^{\circ}$ is due to the poorly bonding between in-dividual printed layers [120]. According to the standard, the failure occurred lateral at the gage in the middle (LGM) for both specimens, with 5 and 10wt.\% of RH. During the test, some specimens showed a premature fracture due to stress concentration areas caused by imperfections during the printing process. These imperfections were produced due to fluctuating diameter; this trouble was already reported [121,122].

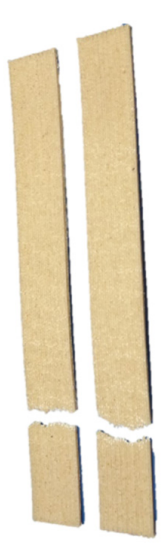

(a)

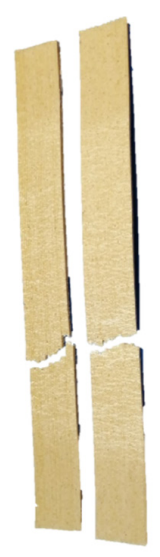

(b)

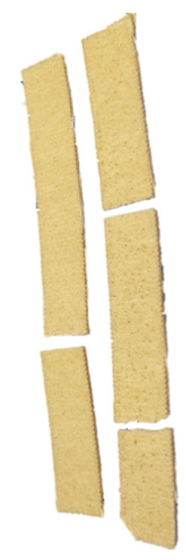

(c)

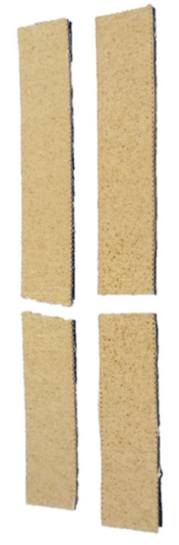

(d)

Figure 7. Tensile test fractured specimens. (a) $\mathrm{rPP} / \mathrm{RH} 5 \mathrm{wt} . \%$ at $0^{\circ}$ : Angled gage bottom (AGB) failure mode; (b) $\mathrm{rPP} / \mathrm{RH}$ $10 \mathrm{wt} \%$ at $0^{\circ}$ : Angled gage middle (AGM) failure mode; (c) $\mathrm{rPP} / \mathrm{RH} 5 \mathrm{wt} . \%$ at $90^{\circ}$ : Lateral gage middle (LGM) failure mode; and (d) rPP/RH 10 wt. $\%$ at $90^{\circ}$ : Lateral gage middle (LGM) failure mode. 


\subsection{Tensile Test Specimens Fracture Morphology}

SEM micrographs of the cross-sectional fracture surfaces of the printed $\mathrm{rPP} / \mathrm{RH}$ composite specimens with different raster angles and compositions are shown at different magnification levels in Figure 8. Figure 8a,b represent printed specimens at $0^{\circ}$, with 5 and $10 \mathrm{wt} . \%$ of $\mathrm{RH}$, respectively. Lengthwise printing pattern can be identified by the filament's cylindrical geometry and the gaps between layers due the poor adhesion. At higher magnification, fiber pull-out and matrix breakage are observed as the main failure mechanism. Non-uniform dispersion of RH in the rPP matrix is observed due to RH particles' irregular morphology and a weak adhesion between the RH and the rPP matrix. This poor interfacial bonding between the RH and rPP and RH agglomerates' presence can be attributed to the low polarity of rPP and the high energy of RH [123]. Filler agglomeration decreased the composite homogeneity and resulted in the void formation, which acted as stress concentrators. These stress concentrators led to the composites' early rupture due to the nonuniform stress [19,124]; this could explain why the specimens' tensile strength drops significantly when RH content is added higher. It is important to highlight that for plant-based composites the limited interaction between the hydrophilic fibers and hydrophobic matrices is generally observed [125]. Physical and mechanical fiber treatment can improve the interfacial bonding between the fiber and the matrix [71,125-127]. The most common chemical treatment is the alkali treatment [128]. During this treatment, the lignin, wax and oil covering natural fibers are removed, increasing the fiber surface's roughness [129]. Reactive coupling agents are also added to improve adhesion between the fiber and the polymer matrix [130].

(a)

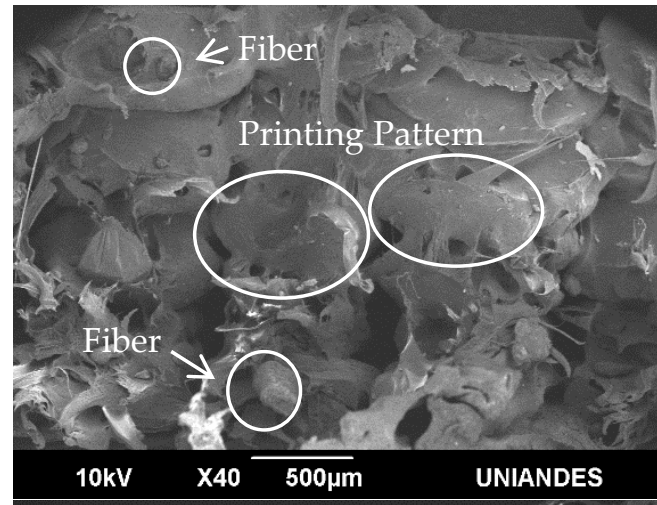

(b)

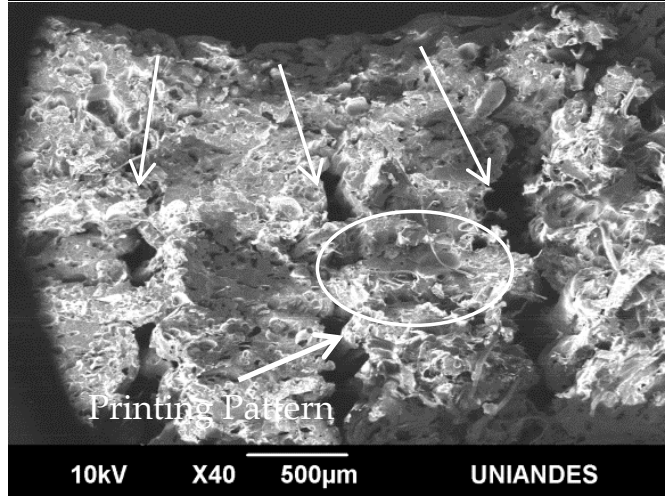

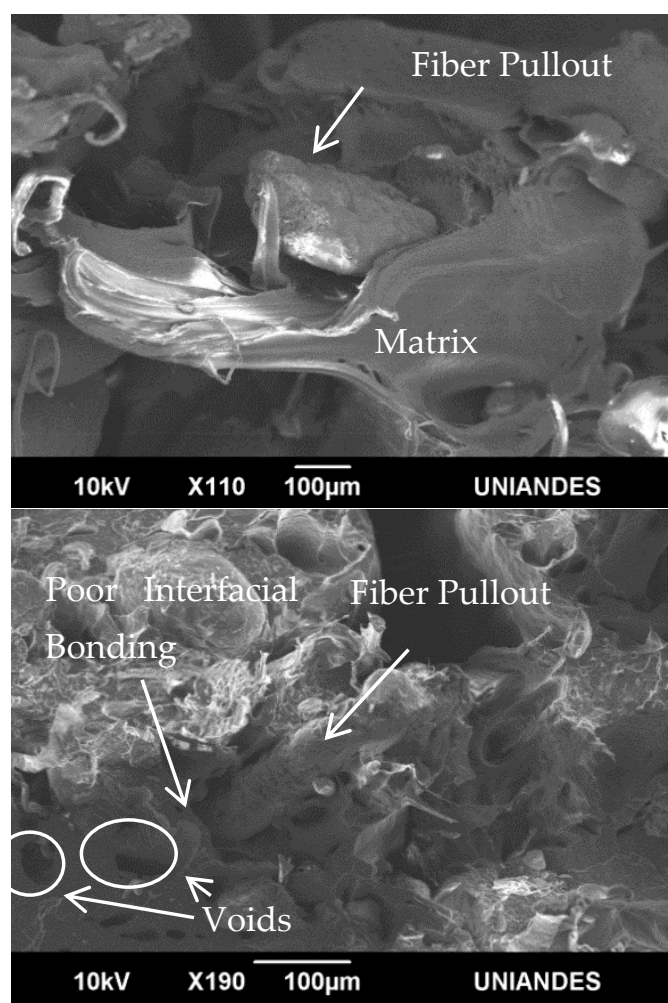

Figure 8. Cont. 
(c)
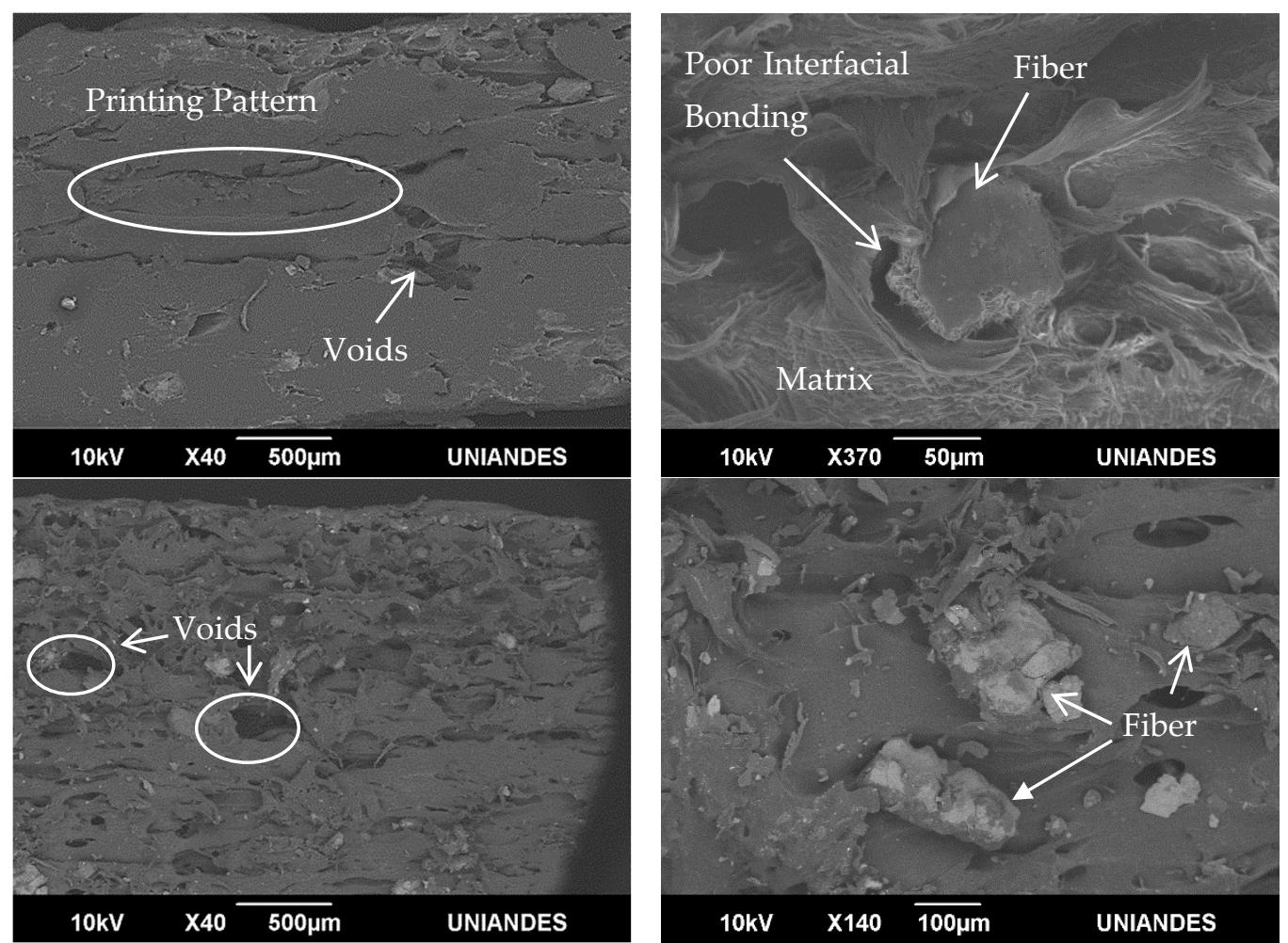

Figure 8. SEM images of tensile fractured specimens. (a) $\mathrm{rPP} / \mathrm{RH} 5$ wt.\%. at $0^{\circ}$; (b) $\mathrm{rPP} / \mathrm{RH} 10 \mathrm{wt} \%$. at $0^{\circ}$; (c) $\mathrm{rPP} / \mathrm{RH} 5$ wt. $\%$. at $90^{\circ}$ and (d) $\mathrm{rPP} / \mathrm{RH} 10 \mathrm{wt} . \%$ at $90^{\circ}$. All the images were acquired at different magnifications in BEC mode.

Figure $8 \mathrm{c}, \mathrm{d}$ show printed specimens at $90^{\circ}$ with 5 and $10 \mathrm{wt} . \%$ of $\mathrm{RH}$, respectively. Figure $8 \mathrm{c}$ shows a mostly layered surface, with a smooth finish in each layer. In these micrographs the specimen failure was attributed to interlayer bonding. The surface is clean, and it does not show any pull-out fibers or holes due to this failure mechanism. However, voids between each layer are observed due to the presence of air between layers during 3D printing process. Moreover, in 3D printing the deposition of molten filaments adjacent to solid layers results in poor interfaces [131]. By contrast, Figure $8 \mathrm{~d}$ shows fiber and matrix breakage as the main failure mechanism, as the broken fibers and fillers are more easily identified.

\section{Conclusions}

In this research, rice husk and recycled polypropylene composite filaments for 3D printing were successfully manufactured and characterized using different rice husk weight ratios and raster angles. The addition of fiber to the neat rPP decreases the warping produced during the printing process. The composite density decreases as the fiber weight ratio increases due to the low density of the fiber. Water absorption and swelling diameter increase in the rPP/RH composites because natural fibers have a hydrophilic behavior. Thermal analysis showed that for $\mathrm{rPP} / \mathrm{RH}$ composites the degradation process started earlier than for the neat rPP due to the fiber's lignocellulosic components, though it does not affect its capability to be printed. On the other hand, the crystallinity increases in the composite material, between 5 to $10 \mathrm{wt} . \%$, because fiber may act as nucleating sites.

Regarding the mechanical properties, the tensile strength decreases using a raster printing angle of $90^{\circ}$ compared to the $0^{\circ}$ printing raster angle. This decrease is due to the weak interlayer bonding. Even though mechanical properties decrease significantly with the introduction of RH in the polymer, they are still attractive for different applications where these mechanical properties are sufficient, as concept parts, lightweight custom jigs and fixtures, and thermoformed parts. Differences between 5 and $10 \mathrm{wt} . \%$ are not 
significant, making rice husk fiber a good filler to be used at $10 \mathrm{wt} . \%$, to take advantage of this agro-industrial waste. Moreover, more fiber content makes the material lighter and more cost-effective than commercial filaments.

SEM micrographs of composite materials confirm the limited interaction between the untreated fiber and rPP matrix related to the reduced strength.

This novel natural rice husk and recycled polypropylene composite material designed as a feedstock filament for 3D printing was evaluated physically, mechanically, and thermally. These properties are useful information to other researchers or end-users to manufacture eco-friendly filaments or printed parts. Based on these results, it can be concluded that 3D printable natural fiber composites based on recycled polymers exhibit low density and low cost, and thus have the potential to be manufactured and find applications in appropriate fields. Natural fibers and recycled polymers make the material sustainable, helping us coming closer to a circular economy.

Author Contributions: Conceptualization, M.A.M. and C.L.A.M.; methodology, M.A.M. and C.L.A.M.; validation, A.M., C.H. and A.P.; formal analysis, M.A.M.; investigation, M.A.M.; writing-original draft preparation and editing, M.A.M.; supervision, A.M., C.H., V.M. and A.P. All authors have read and agreed to the published version of the manuscript.

Funding: This project was funded by the Tech4Dev grant and the Cooperation and Development Center (CODEV) from Ecole Polytechnique Fédérale de Lausanne (EPFL) and the Engineering Faculty from Universidad de los Andes.

Institutional Review Board Statement: Not applicable.

Informed Consent Statement: Not applicable.

Data Availability Statement: The data presented in this study are available upon request from the corresponding author.

Acknowledgments: This project was supported by the EPFL Tech4Dev and the Cooperation and Development Center (CODEV) from EPFL. The authors acknowledge FusedForm for processing advice in the 3D printing process of rPP and composites; Mechanical and Chemical Engineering Department laboratory technicians for their technical support with extrusion process and characterization of the materials; Laboratory for Processing of Advanced Composites (LPAC) from EPFL for the support and supervision.

Conflicts of Interest: The authors declare no conflict of interest.

\section{References}

1. Schwab, K. The Fourth Industrial Revolution, 1st ed.; Crown Business: New York, NY, USA, 2016; ISBN 978-1-5247-5886-8.

2. Markets of Tomorrow: Pathways to a New Economy. Insigth Report. October 2020; World Economic Forum: Cologny, Switzerland, 2020.

3. Klitkou, A.; Bozell, J.; Panoutsou, C.; Kuhndt, M.; Kuusisaari, J.; Beckmann, J. Bioeconomy and Digitalization: Background Paper; MISTRA; The Swedish Foundation for Strategic Environmental Research: Stockholm, Sweden, 2017.

4. Global Agenda Council on the Future of Software and Society World Economic Forum. Deep Shift-Technology Tipping Points and Societal Impact; Survey Report; World Economic Forum: Cologny, Switzerland, 2015.

5. Geyer, R.; Jambeck, J.R.; Law, K.L. Production, Use, and Fate of All Plastics Ever Made. Sci. Adv. 2017, 3, e1700782. [CrossRef] [PubMed]

6. Pol, V.G.; Thiyagarajan, P. Remediating Plastic Waste into Carbon Nanotubes. J. Environ. Monit. 2010, 12, 455-459. [CrossRef]

7. Shah, A.A.; Hasan, F.; Hameed, A.; Ahmed, S. Biological Degradation of Plastics: A Comprehensive Review. Biotechnol. Adv. 2008, 26, 246-265. [CrossRef]

8. Jambeck, J.R.; Geyer, R.; Wilcox, C.; Siegler, T.R.; Perryman, M.; Andrady, A.; Narayan, R.; Law, K.L. Plastic Waste Inputs from Land into the Ocean. Science 2015. [CrossRef]

9. Ahmed, T.; Shahid, M.; Azeem, F.; Rasul, I.; Shah, A.A.; Noman, M.; Hameed, A.; Manzoor, N.; Manzoor, I.; Muhammad, S. Biodegradation of Plastics: Current Scenario and Future Prospects for Environmental Safety. Environ. Sci. Pollut. Res. 2018, 25, 7287-7298. [CrossRef]

10. Barboza, L.G.A.; Dick Vethaak, A.; Lavorante, B.R.B.O.; Lundebye, A.K.; Guilhermino, L. Marine Microplastic Debris: An Emerging Issue for Food Security, Food Safety and Human Health. Marine Pollut. Bull. 2018, 133, 336-348. [CrossRef]

11. Van Cauwenberghe, L.; Janssen, C.R. Microplastics in Bivalves Cultured for Human Consumption. Environ. Pollut. 2014. [CrossRef] [PubMed]

12. Rainieri, S.; Barranco, A. Microplastics, a Food Safety Issue? Trends Food Sci. Technol. 2019, 84, 55-57. [CrossRef] 
13. EFSA. Presence of Microplastics and Nanoplastics in Food, with Particular Focus on Seafood. EFSA J. 2016, 14, e04501. [CrossRef]

14. Marzouk, O.Y.; Dheilly, R.M.; Queneudec, M. Valorization of Post-Consumer Waste Plastic in Cementitious Concrete Composites. Waste Manag. 2007, 27, 310-318. [CrossRef] [PubMed]

15. Singh, N.; Hui, D.; Singh, R.; Ahuja, I.P.S.; Feo, L.; Fraternali, F. Recycling of Plastic Solid Waste: A State of Art Review and Future Applications. Compos. Part B Eng. 2017, 115, 409-422. [CrossRef]

16. Grigore, M.E. Methods of Recycling, Properties and Applications of Recycled Thermoplastic Polymers. Recycling 2017, 2, 24. [CrossRef]

17. Cury, R.K.; Aguas, M.Y.; Martinez, M.A.; Olivero, V.R.; Chams, C.L. Residuos Agroindustriales Su Impacto, Manejo y Aprovechamiento. Rev. Colomb. Cienc. Anim. Recia 2017. [CrossRef]

18. Peñaranda, L.V.; Montenegro, S.P.; Giraldo, P.A. Aprovechamiento de Residuos Agroindustriales En Colombia. Rev. Investig. Agrar. Ambient. 2017, 8, 141-150. [CrossRef]

19. Rice, M.P.; Meurah, T.; Mahlia, I.; Saba, N.; Hassan, A.; Jawaid, M. Mechanical and Thermal Properties of MontmorilloniteReinforced Polypropylene/ Rice Husk Hybrind Nanocomposites. Polymers 2019, 11, 1557. [CrossRef]

20. Basanta, R.; García, M.A.; Cervantes, J.E.; Mata, H.; Bustos, G. Sustainable Recycling of Waste from Sugarcane Agroindustry: A Review. Cienc. Tecnol. Aliment. 2007, 5, 293-305. [CrossRef]

21. Ghiani, G.; Laganà, D.; Manni, E.; Musmanno, R.; Vigo, D. Operations Research in Solid Waste Management: A Survey of Strategic and Tactical Issues. Comput. Oper. Res. 2014, 44, 22-32. [CrossRef]

22. Jiang, L.; Peng, X.; Walczyk, D. 3D Printing of Biofiber-Reinforced Composites and Their Mechanical Properties: A Review. Rapid Prototyp. J. 2020, 26, 1113-1129. [CrossRef]

23. Suthar, S. Recycling of Agro-Industrial Sludge through Vermitechnology. Ecol. Eng. 2010, 36, 1028-1036. [CrossRef]

24. Keskisaari, A.; Kärki, T. The Use of Waste Materials in Wood-Plastic Composites and Their Impact on the Profitability of the Product. Resour. Conserv. Recycl. 2018, 134, 257-261. [CrossRef]

25. Ayre, D. Technology Advancing Polymers and Polymer Composites towards Sustainability: A Review. Curr. Opin. Green Sustain. Chem. 2018, 13, 108-112. [CrossRef]

26. Ricciardi, P.; Cillari, G.; Carnevale Miino, M.; Collivignarelli, M.C. Valorization of Agro-Industry Residues in the Building and Environmental Sector: A Review. Waste Manag. Res. 2020, 38, 487-513. [CrossRef] [PubMed]

27. Go, J.; Hart, A.J. A Framework for Teaching the Fundamentals of Additive Manufacturing and Enabling Rapid Innovation. Addit. Manuf. 2016. [CrossRef]

28. Brooks, H.; Molony, S. Design and Evaluation of Additively Manufactured Parts with Three Dimensional Continuous Fibre Reinforcement. Mater. Des. 2016. [CrossRef]

29. Yang, T.C. Effect of Extrusion Temperature on the Physico-Mechanical Properties of Unidirectional Wood Fiber-Reinforced Polylactic Acid Composite (WFRPC) Components Using Fused Depositionmodeling. Polymers 2018, 10, 976. [CrossRef]

30. Ning, F.; Cong, W.; Qiu, J.; Wei, J.; Wang, S. Additive Manufacturing of Carbon Fiber Reinforced Thermoplastic Composites Using Fused Deposition Modeling. Compos. Part B Eng. 2015, 80, 369-378. [CrossRef]

31. Galantucci, L.M.; Lavecchia, F.; Percoco, G. Quantitative Analysis of a Chemical Treatment to Reduce Roughness of Parts Fabricated Using Fused Deposition Modeling. Cirp Ann. Manuf. Technol. 2010. [CrossRef]

32. Chinga-Carrasco, G.; Ehman, N.V.; Pettersson, J.; Vallejos, M.E.; Brodin, M.W.; Felissia, F.E.; Hakansson, J.; Area, M.C. Pulping and Pretreatment Affect the Characteristics of Bagasse Inks for Three-Dimensional Printing. ACS Sustain. Chem. Eng. 2018. [CrossRef]

33. Bandyopadhyay, A.; Bose, S.; Das, S. 3D Printing of Biomaterials. MRS Bull. 2015. [CrossRef]

34. Ji, A.; Zhang, S.; Bhagia, S.; Yoo, C.G.; Ragauskas, A.J. 3D Printing of Biomass-Derived Composites: Application and Characterization Approaches. RSC Adv. 2020, 10, 21698-21723. [CrossRef]

35. Wang, P.; Zou, B.; Xiao, H.; Ding, S.; Huang, C. Effects of Printing Parameters of Fused Deposition Modeling on Mechanical Properties, Surface Quality, and Microstructure of PEEK. J. Mater. Process. Technol. 2019, 271, 62-74. [CrossRef]

36. Jaisingh Sheoran, A.; Kumar, H. Fused Deposition Modeling Process Parameters Optimization and Effect on Mechanical Properties and Part Quality: Review and Reflection on Present Research. Mater. Today Proc. 2020, 21, 1659-1672. [CrossRef]

37. Yang, C.; Tian, X.; Liu, T.; Cao, Y.; Li, D. 3D Printing for Continuous Fiber Reinforced Thermoplastic Composites: Mechanism and Performance. Rapid Prototyp. J. 2017. [CrossRef]

38. Klippstein, H.; Diaz De Cerio Sanchez, A.; Hassanin, H.; Zweiri, Y.; Seneviratne, L. Fused Deposition Modeling for Unmanned Aerial Vehicles (UAVs): A Review. Adv. Eng. Mater. 2018, 20, 1700552. [CrossRef]

39. Diaz-Perete, D.; Mercado-Colmenero, J.M.; Valderrama-Zafra, J.M.; Martin-Doñate, C. New Procedure for BIM Characterization of Architectural Models Manufactured Using Fused Deposition Modeling and Plastic Materials in 4.0 Advanced Construction Environments. Polymers 2020, 12, 1498. [CrossRef]

40. Belka, M.; Ulenberg, S.; Baczek, T. Fused Deposition Modeling Enables the Low-Cost Fabrication of Porous, Customized-Shape Sorbents for Small-Molecule Extraction. Anal. Chem. 2017, 89, 4373-4376. [CrossRef]

41. Guerrica-Echevarría, G.; Eguiazábal, J.I.; Nazábal, J. Effects of Reprocessing Conditions on the Properties of Unfilled and Talc-Filled Polypropylene. Polym. Degrad. Stab. 1996. [CrossRef]

42. Chabowski, B.R.; Mena, J.A.; Gonzalez-Padron, T.L. The Structure of Sustainability Research in Marketing, 1958-2008: A Basis for Future Research Opportunities. J. Acad. Mark. Sci. 2011. [CrossRef] 
43. Fitzharris, E.R.; Watanabe, N.; Rosen, D.W.; Shofner, M.L. Effects of Material Properties on Warpage in Fused Deposition Modeling Parts. Int. J. Adv. Manuf. Technol. 2018, 95, 2059-2070. [CrossRef]

44. Pickering, K.; Stoof, D. Sustainable Composite Fused Deposition Modelling Filament Using Post-Consumer Recycled Polypropylene. J. Compos. Sci. 2017, 1, 17. [CrossRef]

45. Le Duigou, A.; Castro, M.; Bevan, R.; Martin, N. 3D Printing of Wood Fibre Biocomposites: From Mechanical to Actuation Functionality. Mater. Des. 2016. [CrossRef]

46. Lebedev, S.M.; Gefle, O.S.; Amitov, E.T.; Zhuravlev, D.V.; Berchuk, D.Y.; Mikutskiy, E.A. Mechanical Properties of PLA-Based Composites for Fused Deposition Modeling Technology. Int. J. Adv. Manuf. Technol. 2018, 97, 511-518. [CrossRef]

47. Travieso-Rodriguez, J.A.; Zandi, M.D.; Jerez-Mesa, R.; Lluma-Fuentes, J. Fatigue Behavior of PLA-Wood Composite Manufactured by Fused Filament Fabrication. J. Mater. Res. Technol. 2020, 9, 8507-8516. [CrossRef]

48. Landes, S.; Letcher, T. Mechanical Strength of Bamboo Filled PLA Composite Material in Fused Filament Fabrication. J. Compos. Sci. 2020, 4, 159. [CrossRef]

49. Caminero, M.; Chacón, J.; García-Plaza, E.; Núñez, P.; Reverte, J.; Becar, J. Additive Manufacturing of PLA-Based Composites Using Fused Filament Fabrication: Effect of Graphene Nanoplatelet Reinforcement on Mechanical Properties, Dimensional Accuracy and Texture. Polymers 2019, 11, 799. [CrossRef] [PubMed]

50. Zandi, M.D.; Jerez-Mesa, R.; Lluma-Fuentes, J.; Jorba-Peiro, J.; Travieso-Rodriguez, J.A. Study of the Manufacturing Process Effects of Fused Filament Fabrication and Injection Molding on Tensile Properties of Composite PLA-Wood Parts. Int. J. Adv. Manuf. Technol. 2020, 108, 1725-1735. [CrossRef]

51. Reverte, J.M.; Caminero, M.Á.; Chacón, J.M.; García-Plaza, E.; Núñez, P.J.; Becar, J.P. Mechanical and Geometric Performance of PLA-Based Polymer Composites Processed by the Fused Filament Fabrication Additive Manufacturing Technique. Materials 2020, 13, 1924. [CrossRef]

52. Rejeski, D.; Zhao, F.; Huang, Y. Research Needs and Recommendations on Environmental Implications of Additive Manufacturing. Addit. Manuf. 2018, 19, 21-28. [CrossRef]

53. Ahmed, W.; Alnajjar, F.; Zaneldin, E.; Al-Marzouqi, A.H.; Gochoo, M.; Khalid, S. Implementing FDM 3D Printing Strategies Using Natural Fibers to Produce Biomass Composite. Materials 2020, 13, 4065. [CrossRef] [PubMed]

54. Beckermann, G. Performance of Hemp-Fibre Reinforced Polypropylene Composite Materials. Ph.D. Thesis, University of Waikato, Hamilton, New Zeland, 2007.

55. Mazzanti, V.; Malagutti, L.; Mollica, F. FDM 3D Printing of Polymers Containing Natural Fillers: A Review of Their Mechanical Properties. Polymers 2019, 11, 1094. [CrossRef]

56. Huang, B.; He, H.; Meng, S.; Jia, Y. Optimizing 3D Printing Performance of Acrylonitrile-butadiene-styrene Composites with Cellulose Nanocrystals/Silica Nanohybrids. Polym. Int. 2019, 68, 1351-1360. [CrossRef]

57. Le Duigou, A.; Correa, D.; Ueda, M.; Matsuzaki, R.; Castro, M. A Review of 3D and 4D Printing of Natural Fibre Biocomposites. Mater. Des. 2020, 194, 108911. [CrossRef]

58. Wang, Q.; Sun, J.; Yao, Q.; Ji, C.; Liu, J.; Zhu, Q. 3D Printing with Cellulose Materials. Cellulose 2018, 25, 4275-4301. [CrossRef]

59. Le Guen, M.J.; Hill, S.; Smith, D.; Theobald, B.; Gaugler, E.; Barakat, A.; Mayer-Laigle, C. Influence of Rice Husk and Wood Biomass Properties on the Manufacture of Filaments for Fused Deposition Modeling. Front. Chem. 2019, 7. [CrossRef]

60. Liles, K.P.; Greene, A.F.; Danielson, M.K.; Colley, N.D.; Wellen, A.; Fisher, J.M.; Barnes, J.C. Photoredox-Based Actuation of an Artificial Molecular Muscle. Macromol. Rapid Commun. 2018, 39, 1700781. [CrossRef]

61. Deb, D.; Jafferson, J.M. Natural Fibers Reinforced FDM 3D Printing Filaments. Mater. Today Proc. 2021, S2214785321015170. [CrossRef]

62. Li, X.; Tabil, L.G.; Panigrahi, S. Chemical Treatments of Natural Fiber for Use in Natural Fiber-Reinforced Composites: A Review. J. Polym. Environ. 2007, 15, 25-33. [CrossRef]

63. Balla, V.K.; Tadimeti, J.G.D.; Kate, K.H.; Satyavolu, J. 3D Printing of Modified Soybean Hull Fiber/Polymer Composites. Mater. Chem. Phys. 2020, 254, 123452. [CrossRef]

64. Balla, V.K.; Kate, K.H.; Satyavolu, J.; Singh, P.; Tadimeti, J.G.D. Additive Manufacturing of Natural Fiber Reinforced Polymer Composites: Processing and Prospects. Compos. Part B Eng. 2019, 174, 106956. [CrossRef]

65. Tsou, C.H.; Yao, W.H.; Wu, C.S.; Tsou, C.Y.; Hung, W.S.; Chen, J.C.; Guo, J.; Yuan, S.; Wen, E.; Wang, R.Y.; et al. Preparation and Characterization of Renewable Composites from Polylactide and Rice Husk for 3D Printing Applications. J. Polym. Res. 2019, 26. [CrossRef]

66. Wu, C.S.; Tsou, C.H. Fabrication, Characterization, and Application of Biocomposites from Poly(Lactic Acid) with Renewable Rice Husk as Reinforcement. J. Polym. Res. 2019, 26. [CrossRef]

67. Cisneros-López, E.O.; Pal, A.K.; Rodriguez, A.U.; Wu, F.; Misra, M.; Mielewski, D.F.; Kiziltas, A.; Mohanty, A.K. Recycled Poly(Lactic Acid)-Based 3D Printed Sustainable Biocomposites: A Comparative Study with Injection Molding. Mater. Today Sustain. 2020, 7-8, 100027. [CrossRef]

68. Carrete, I.A.; Quiñonez, P.A.; Bermudez, D.; Roberson, D.A. Incorporating Textile-Derived Cellulose Fibers for the Strengthening of Recycled Polyethylene Terephthalate for 3D Printing Feedstock Materials. J. Polym. Environ. 2021, 29, 662-671. [CrossRef]

69. Zander, N.E.; Gillan, M.; Burckhard, Z.; Gardea, F. Recycled Polypropylene Blends as Novel 3D Printing Materials. Addit. Manuf. 2019, 25, 122-130. [CrossRef] 
70. Stoof, D.; Pickering, K. Sustainable Composite Fused Deposition Modelling Filament Using Recycled Pre-Consumer Polypropylene. Compos. Part B Eng. 2018, 135, 110-118. [CrossRef]

71. Milosevic, M.; Stoof, D.; Pickering, K.L. Characterizing the Mechanical Properties of Fused Deposition Modelling Natural Fiber Recycled Polypropylene Composites. J. Compos. Sci. 2017, 1, 7. [CrossRef]

72. Spoerk, M.; Holzer, C.; Gonzalez-Gutierrez, J. Material Extrusion-based Additive Manufacturing of Polypropylene: A Review on How to Improve Dimensional Inaccuracy and Warpage. J. Appl. Polym. Sci. 2020, 137, 48545. [CrossRef]

73. Spoerk, M.; Sapkota, J.; Weingrill, G.; Fischinger, T.; Arbeiter, F.; Holzer, C. Shrinkage and Warpage Optimization of ExpandedPerlite-Filled Polypropylene Composites in Extrusion-Based Additive Manufacturing. Macromol. Mater. Eng. 2017, $302,1700143$. [CrossRef]

74. Plásticos En Colombia 2020-2021. Available online: https:/ /www.acoplasticos.org/index.php/mnu-nos/mnu-pyr/mnu-pyr-pi/ 378 (accessed on 17 March 2021).

75. Acosta-Coley, I.; Olivero-Verbel, J. Microplastic Resin Pellets on an Urban Tropical Beach in Colombia. Environ. Monit. Assess. 2015, 187, 435. [CrossRef]

76. Mourad, A.H.I.; Akkad, R.O.; Soliman, A.A.; Madkour, T.M. Characterisation of Thermally Treated and Untreated PolyethylenePolypropylene Blends Using DSC, TGA and IR Techniques. Plast. Rubber Compos. 2009, 38, 265-278. [CrossRef]

77. Osswald, T.A.; Hernández-Ortiz, J.P. Polymer Processing; Carl Hanser Verlag GmbH \& Co. KG: München, Germany, 2006; ISBN 978-3-446-40381-9.

78. Qahtani, M.; Wu, F.; Misra, M.; Gregori, S.; Mielewski, D.F.; Mohanty, A.K. Experimental Design of Sustainable 3D-Printed Poly(Lactic Acid)/Biobased Poly(Butylene Succinate) Blends via Fused Deposition Modeling. ACS Sustain. Chem. Eng. 2019, 7, 14460-14470. [CrossRef]

79. Joseph, P.V.; Joseph, K.; Thomas, S.; Pillai, C.K.S.; Prasad, V.S.; Groeninckx, G.; Sarkissova, M. The Thermal and Crystallisation Studies of Short Sisal Fibre Reinforced Polypropylene Composites. Compos. Part Appl. Sci. Manuf. 2003, 34, 253-266. [CrossRef]

80. Hidalgo-Salazar, M.A.; Muñoz, M.F.; Mina, J.H. Influence of Incorporation of Natural Fibers on the Physical, Mechanical, and Thermal Properties of Composites LDPE-Al Reinforced with Fique Fibers. Int. J. Polym. Sci. 2015, 2015, 1-8. [CrossRef]

81. van der Wal, A.; Mulder, J.J.; Gaymans, R.J. Fracture of Polypropylene. Polymer 1998, 39, 5477-5481. [CrossRef]

82. Lanyi, F.J.; Wenzke, N.; Kaschta, J.; Schubert, D.W. On the Determination of the Enthalpy of Fusion of A-Crystalline Isotactic Polypropylene Using Differential Scanning Calorimetry, X-Ray Diffraction, and Fourier-Transform Infrared Spectroscopy: An Old Story Revisited. Adv. Eng. Mater. 2020, 22, 1900796. [CrossRef]

83. De Sousa, R.R., Jr.; Gouveia, J.R.; Nacas, A.M.; Tavares, L.B.; Ito, N.M.; de Moura, E.N.; Gaia, F.A.; Pereira, R.F.; dos Santos, D.J. Improvement of Polypropylene Adhesion by Kraft Lignin Incorporation. Mater. Res. 2019, 22, e20180123. [CrossRef]

84. Montgomery, D.C. Design and Analysis of Experiments, 8th ed.; John Wiley \& Sons: Hoboken, NY, USA, 2012; ISBN 978-1-11814692-7.

85. Olupot, P.W.; Candia, A.; Menya, E.; Walozi, R. Characterization of Rice Husk Varieties in Uganda for Biofuels and Their Techno-Economic Feasibility in Gasification. Chem. Eng. Res. Des. 2016, 107, 63-72. [CrossRef]

86. Shakuntala, O.; Raghavendra, G.; Samir Kumar, A. Effect of Filler Loading on Mechanical and Tribological Properties of Wood Apple Shell Reinforced Epoxy Composite. Adv. Mater. Sci. Eng. 2014, 2014, 1-9. [CrossRef]

87. Salgado, P.R.; Schmidt, V.C.; Molina Ortiz, S.E.; Mauri, A.N.; Laurindo, J.B. Biodegradable Foams Based on Cassava Starch, Sunflower Proteins and Cellulose Fibers Obtained by a Baking Process. J. Food Eng. 2008, 85, 435-443. [CrossRef]

88. Edhirej, A.; Sapuan, S.M.; Jawaid, M.; Zahari, N.I. Cassava/Sugar Palm Fiber Reinforced Cassava Starch Hybrid Composites: Physical, Thermal and Structural Properties. Int. J. Biol. Macromol. 2017, 101, 75-83. [CrossRef]

89. D20 Committee. ASTM D792 -20 Test Methods for Density and Specific Gravity (Relative Density) of Plastics by Displacement; ASTM International: West Conshohcken, PA, USA, 2008.

90. Holbery, J.; Houston, D. Natural-Fiber-Reinforced Polymer Composites in Automotive Applications. JOM 2006, 58, 80-86. [CrossRef]

91. Westman, M.P.; Fifield, L.S.; Simmons, K.L.; Laddha, S.; Kafentzis, T.A. Natural Fiber Composites: A Review; U.S. Department of Energy: Washington, DC, USA, 2010; p. PNNL-19220. [CrossRef]

92. Verma, D.; Senal, I. Natural fiber-reinforced polymer composites. In Biomass, Biopolymer-Based Materials, and Bioenergy; Elsevier: Amsterdam, The Netherlands, 2019; pp. 103-122. ISBN 978-0-08-102426-3.

93. Ouarhim, W.; Zari, N.; Bouhfid, R.; Qaiss, A. Mechanical performance of natural fibers—based thermosetting composites. In Mechanical and Physical Testing of Biocomposites, Fibre-Reinforced Composites and Hybrid Composites; Jawaid, M., Thariq, M., Saba, N., Eds.; Woodhead Publishing Series in Composites Science and Engineering; Woodhead Publishing: Cambridge, UK, 2019; Chapter 3; pp. 43-60. ISBN 978-0-08-102292-4.

94. Rahman, R.; Zhafer Firdaus Syed Putra, S. Tensile properties of natural and synthetic fiber-reinforced polymer composites. In Mechanical and Physical Testing of Biocomposites, Fibre-Reinforced Composites and Hybrid Composites; Jawaid, M., Thariq, M., Saba, N., Eds.; Woodhead Publishing Series in Composites Science and Engineering; Woodhead Publishing: Cambridge, UK, 2019; Chapter 5; pp. 81-102. ISBN 978-0-08-102292-4.

95. Thyavihalli Girijappa, Y.G.; Mavinkere Rangappa, S.; Parameswaranpillai, J.; Siengchin, S. Natural Fibers as Sustainable and Renewable Resource for Development of Eco-Friendly Composites: A Comprehensive Review. Front. Mater. 2019, 6. [CrossRef] 
96. Razavi-Nouri, M.; Jafarzadeh, F.; Oromiehie, A.; Langroudi, A. Mechanical Properties and Water Absorption Behaviour of Chopped Rice Husk Filled Polypropylene Composites. Iran. Polym. J. Engl. Ed. 2006, 15, 757-766.

97. Le Duigou, A.; Bourmaud, A.; Davies, P.; Baley, C. Long Term Immersion in Natural Seawater of Flax/PLA Biocomposite. Ocean Eng. 2014, 90, 140-148. [CrossRef]

98. Gholampour, A.; Ozbakkaloglu, T. A Review of Natural Fiber Composites: Properties, Modification and Processing Techniques, Characterization, Applications. J. Mater. Sci. 2020, 55, 829-892. [CrossRef]

99. Al-Maharma, A.; Al-Huniti, N. Critical Review of the Parameters Affecting the Effectiveness of Moisture Absorption Treatments Used for Natural Composites. J. Compos. Sci. 2019, 3, 27. [CrossRef]

100. Pan, Y.; Zhong, Z. A Nonlinear Constitutive Model of Unidirectional Natural Fiber Reinforced Composites Considering Moisture Absorption. J. Mech. Phys. Solids 2014, 69, 132-142. [CrossRef]

101. Banik, N.; Dey, V.; Sastry, G.R.K. An Overview of Lignin \& Hemicellulose Effect Upon Biodegradable Bamboo Fiber Composites Due to Moisture. Mater. Today Proc. 2017, 4, 3222-3232. [CrossRef]

102. Jauhari, N.; Mishra, R.; Thakur, H. Natural Fibre Reinforced Composite Laminates-A Review. Mater. Today Proc. 2015, 2, 2868-2877. [CrossRef]

103. Joseph, S. A Comparison of the Mechanical Properties of Phenol Formaldehyde Composites Reinforced with Banana Fibres and Glass Fibres. Compos. Sci. Technol. 2002, 62, 1857-1868. [CrossRef]

104. Ho, M.; Wang, H.; Lee, J.-H.; Ho, C.; Lau, K.; Leng, J.; Hui, D. Critical Factors on Manufacturing Processes of Natural Fibre Composites. Compos. Part B Eng. 2012, 43, 3549-3562. [CrossRef]

105. Yashas Gowda, T.G.; Sanjay, M.R.; Subrahmanya Bhat, K.; Madhu, P.; Senthamaraikannan, P.; Yogesha, B. Polymer Matrix-Natural Fiber Composites: An Overview. Cogent Eng. 2018, 5, 1446667. [CrossRef]

106. Aji, I.; Zainudin, E.; Abdan, K.; Sapuan, S.; Khairul, M. Mechanical Properties and Water Absorption Behavior of Hybridized Kenaf/Pineapple Leaf Fibre-Reinforced High-Density Polyethylene Composite. J. Compos. Mater. 2013, 47, 979-990. [CrossRef]

107. Zaman, H.U.; Beg, M. Preparation, Structure, and Properties of the Coir Fiber/Polypropylene Composites. J. Compos. Mater. 2014, 48, 3293-3301. [CrossRef]

108. Montalvo Navarrete, J.I.; Hidalgo-Salazar, M.A.; Escobar Nunez, E.; Rojas Arciniegas, A.J. Thermal and Mechanical Behavior of Biocomposites Using Additive Manufacturing. Int. J. Interact. Des. Manuf. IJIDeM 2018, 12, 449-458. [CrossRef]

109. Tran, T.N.; Bayer, I.S.; Heredia-Guerrero, J.A.; Frugone, M.; Lagomarsino, M.; Maggio, F.; Athanassiou, A. Cocoa Shell Waste Biofilaments for 3D Printing Applications. Macromol. Mater. Eng. 2017, 302, 1-10. [CrossRef]

110. Pet, P.P.; Composites, M. Development of Crystalline Morphology and Its Relationship with Mechanical Properties Of PP/PET Microfibrillar Composites Containing POE and Poe-g-MA. Polymers 2018, 10, 291. [CrossRef]

111. Tao, Y.; Wang, H.; Li, Z.; Li, P.; Shi, S.Q. Development and Application Ofwood Flour-Filled Polylactic Acid Composite Filament for 3d Printing. Materials 2017, 10, 339. [CrossRef]

112. Girdis, J.; Gaudion, L.; Proust, G.; Löschke, S.; Dong, A. Rethinking Timber: Investigation into the Use of Waste Macadamia Nut Shells for Additive Manufacturing. JOM 2017, 69, 575-579. [CrossRef]

113. Siqueira, G.; Fraschini, C.; Bras, J.; Dufresne, A.; Prud'Homme, R.; Laborie, M.P. Impact of the Nature and Shape of Cellulosic Nanoparticles on the Isothermal Crystallization Kinetics of Poly(-Caprolactone). Eur. Polym. J. 2011. [CrossRef]

114. Zeidler, H.; Klemm, D.; Böttger-Hiller, F.; Fritsch, S.; Le Guen, M.J.; Singamneni, S. 3D Printing of Biodegradable Parts Using Renewable Biobased Materials. Proc. Manuf. 2018, 21, 117-124. [CrossRef]

115. Osman, M.A.; Atia, M.R.A. Investigation of ABS-Rice Straw Composite Feedstock Filament for FDM. Rapid Prototyp. J. 2018. [CrossRef]

116. Tisserat, B.; Liu, Z.; Finkenstadt, V.; Lewandowski, B.; Ott, S.; Reifschneider, L. 3D Printing Biocomposites. Spe Plast. Res. Online 2015. [CrossRef]

117. Šafka, J.; Ackermann, M.; Bobek, J.; Seidl, M.; Habr, J.; Běhálek, L. Use of Composite Materials for FDM 3D Print Technology. Mater. Sci. Forum 2016, 862, 174-181. [CrossRef]

118. Gkartzou, E.; Koumoulos, E.P.; Charitidis, C.A. Production and 3D Printing Processing of Bio-Based Thermoplastic Filament. Manuf. Rev. 2017. [CrossRef]

119. Liu, H.; He, H.; Peng, X.; Huang, B.; Li, J. Three-Dimensional Printing of Poly(Lactic Acid) Bio-Based Composites with Sugarcane Bagasse Fiber: Effect of Printing Orientation on Tensile Performance. Polym. Adv. Technol. 2019. [CrossRef]

120. Askeland, D.R.; Fulay, P.P.; Wright, W.J. The Science and Engineering of Materials, 6th ed.; Cengage Learning: Boston, MA, USA, 2011; ISBN 978-0-495-29602-7.

121. Rajpurohit, S.R.; Dave, H.K. Analysis of Tensile Strength of a Fused Filament Fabricated PLA Part Using an Open-Source 3D Printer. Int. J. Adv. Manuf. Technol. 2019, 101, 1525-1536. [CrossRef]

122. Garg, A.; Bhattacharya, A.; Batish, A. Chemical Vapor Treatment of ABS Parts Built by FDM: Analysis of Surface Finish and Mechanical Strength. Int. J. Adv. Manuf. Technol. 2017, 89, 2175-2191. [CrossRef]

123. Bendahou, A.; Kaddami, H.; Sautereau, H.; Raihane, M.; Erchiqui, F.; Dufresne, A. Short Palm Tree Fibers Poly Olefin Composites: Effect of Filler Content and Coupling Agent on Physical Properties. Macromol. Mater. Eng. 2008. [CrossRef]

124. Chen, P.; Lu, C.; Yu, Q.; Gao, Y.; Li, J.; Li, X. Influence of Fiber Wettability on the Interfacial Adhesion of Continuous FiberReinforced PPESK Composite. J. Appl. Polym. Sci. 2006. [CrossRef] 
125. Pickering, K.L.; Efendy, M.G.A.; Le, T.M. A Review of Recent Developments in Natural Fibre Composites and Their Mechanical Performance. Compos. Part Appl. Sci. Manuf. 2016, 83, 98-112. [CrossRef]

126. Sinha, E.; Panigrahi, S. Effect of Plasma Treatment on Structure, Wettability of Jute Fiber and Flexural Strength of Its Composite. J. Compos. Mater. 2009, 43, 1791-1802. [CrossRef]

127. Filgueira, D.; Holmen, S.; Melbø, J.K.; Moldes, D.; Echtermeyer, A.T.; Chinga-Carrasco, G. 3D Printable Filaments Made of Biobased Polyethylene Biocomposites. Polymers 2018, 10, 314. [CrossRef]

128. Sood, M.; Dwivedi, G. Effect of Fiber Treatment on Flexural Properties of Natural Fiber Reinforced Composites: A Review. Egypt. J. Pet. 2018, 27, 775-783. [CrossRef]

129. Manalo, A.C.; Wani, E.; Zukarnain, N.A.; Karunasena, W.; Lau, K.T. Effects of Alkali Treatment and Elevated Temperature on the Mechanical Properties of Bamboo Fibre-Polyester Composites. Compos. Part B Eng. 2015. [CrossRef]

130. Sood, M.; Dharmpal, D.; Gupta, V.K. Effect of Fiber Chemical Treatment on Mechanical Properties of Sisal Fiber/Recycled HDPE Composite. Mater. Today Proc. 2015, 2, 3149-3155. [CrossRef]

131. van de Werken, N.; Hurley, J.; Khanbolouki, P.; Sarvestani, A.N.; Tamijani, A.Y.; Tehrani, M. Design Considerations and Modeling of Fiber Reinforced 3D Printed Parts. Compos. Part B Eng. 2019, 160, 684-692. [CrossRef] 